\title{
How the Crowding-out Effect Hypothesis Stands Under a Financial System Liberalised: The Mexican Economy Case
}

\author{
Benjamin Garcia Paez ${ }^{1}$ \\ ${ }^{1}$ Department of Economics, National University of Mexico (UNAM), Mexico City, Mexico \\ Correspondence: Benjamin Garcia Paez, Department of Economics, National University of Mexico (UNAM), \\ Mexico City, Mexico. Tel: 525-518-384-986. E-mail: garpaez@unam.mx
}

Received: September 30, 2021

Accepted: October 25, 2021

Online Published: October 28, 2021

doi:10.5430/ijfr.v12n5p246

URL: https://doi.org/10.5430/ijfr.v12n5p246

\begin{abstract}
This paper revisits the financial-liberalisation hypothesis predicting one negative effect of public investment on private investment, which led to the de-regularisation of the financial system in Mexico and many other Less-developed Countries (LDCs) so as to probe whether such tenet hold today even when the role played by the public sector has evolved from having a direct intervention in credit allocation scheme to the fulfilment of a limited duties such as the surveillance of the money and capital markets under a financial liberalization environment. Considering Mexico as a case study, an econometric exercise over the 1970-2019 period is tried crunching official statistical data. Besides a brief introduction, the second section discusses theoretical issues concerning the effects of public investment on private investment, likewise some empirical work done in this field. The third section develops the methodology used to taste the net effect of public investment on private investment and presents also the results estimates. Finally, some conclusions derived from the empirical evidence found in the analysis and a brief discussion are laid down.
\end{abstract}

Keywords: repressed financial system, liberalised financial system, crowding-out, crowding-in, Mexican economy

\section{Introduction}

At the beginning of 1988, the Mexican government put forward a thorough financial sector liberalization programme in a series of structural economic reforms, leading to the re-privatization of the commercial banks (1989), which were at that time the largest financial intermediaries and the main providers of the credit.

Until 1989, commercial banks operated under quantitative and interest rate controls. Extensive sectoral credit targets and a complex system of reserve and liquidity requirements channelled credit to administratively determined priority uses, leaving less than $50 \%$ of credit not subject to sectoral targets and interest rate controls. Furthermore, a system of special loan tranches operated through which commercial banks lent at subsidised rates a fixed percentage of their deposit liabilities to the agricultural, exports, industrial and housing sectors (Table 1). This table shows the reserve rates for three years: before commercial banks nationalisation (1980), the period they remained nationalised (1987) and after financial liberalisation (1990). (Warman \& Thirlwall, 1994)

Table 1. Compulsory Reserve Requirements (\%)

\begin{tabular}{lccc}
\hline & 1980 & 1987 & $1990-2019$ \\
\hline Cash Reserves & 1.7 & - & - \\
Deposits in Bank of Mexico $^{(1)}$ & 38.8 & 10 & - \\
Treasury Bills & - & - & 30 \\
Credit to Federal Government & - & 35 & - \\
Credit to Agriculture & 5.4 & 4.7 & - \\
Credit to Sector Housing $^{(2)}$ & 7.8 & 8.5 & - \\
Credit to Industrial Sector $^{(2)}$ & 4.1 & 4.9 & - \\
\hline
\end{tabular}




TOTAL
Compulsory reserve requirements on the stock of domestic currency denominated deposit liabilities of
commercial banks.
${ }^{(1)}$ Interest yielding deposits in the Bank of Mexico.
${ }^{(2)}$ Small and medium size firms.
${ }^{(3)}$ After 1989, commercial banks were required to invest 30\% of their deposit liabilities in treasury bills.

Source: Banco de Mexico (2021).

As for the credit given by development banks, the major part was assigned to finance the deficit of the public sector. After the liberalisation of the financial system, the number and government trust funds were reduced through privatisation programmes, mergers, and closures. Incidentally, the existing government-owned funds provided credit at subsidised rates to the agricultural sector, the housing sector, trading activities and to the tourism sector. Notwithstanding, the main features must be with the changes in the role of central bank from a regulated financial system to a market-forces led economy. A redesign in line with the Financial Liberalisation Theory, let alone the external pressure of the multilateral financial institutions likewise the neoliberal policies advocated by developed countries. (Cypher \& Dietz, 1997)

It is argued by the financial liberalisation model that for a liberalised financial market to work efficiently is the reduction of the public sector's deficit as a high amount of that needs massive financing ends up distorting financial markets and the government must resort to the use of policies and instruments, such as credit ceilings and reserve requirements, among others, which have a propensity to divert financial resources to the public sector.

The policy implications of that tenet are so enduring that even until now the public deficit reduction continues standing up at the core of the Mexican economic policy and has affected the public investment overall (Note 1). Incidentally, the credit given to the public sector increased its percentage share in total credit after 1982, coinciding with the period when participation of public investment in total public expenditure fell sharply due to such credit was mainly devoted to finance interest payments on the domestic public debt.

As the surge in the so-called intangible nature of capital and activity in the modern economy (Haskel \& Stian, 2018), has caught many LDCs without both the lack of clarity about what contributes to the economic process of structural transformation and the setting up the virtuous circle between productivity increases and the inducement to invest (Ros, 2013).

So, the raison d'être of this research is to analyse the effects that a change of public investment has on private investment. This a most controversial issue because the effect of public investment on private investment is subject to both crowding-in or complementarity effect and a crowding-out or substitution effect. In this perspective, following the presentation of a discussion and previous empirical work done on this topic, two recursive models are developed to find out estimates of the net effect of a change in in public investment on private investment: the crowding-in effect less the crowding-out effect.

\section{The Underpinning Economic Theory}

The effect of public investment on private investment is ambiguous at a theoretical level since two opposing effects can occur simultaneously: a crowding-in and a crowding-out effect. Public investment is complementary to private investment (crowding-in) if an initial increase in the former leads to an increase in the latter, otherwise it crowd-out private investment. There are several reasons why there might be a contributory relation between public and private investment. If there are unemployed resources, an increase in public investment raises the level of aggregate demand and widens the size of the market for private production. Furthermore, a high percentage of public investment is devoted to public works in infrastructure creating economies of scale and increasing the productivity and profitability of private investment. Private investment is thus stimulated by the rise in the expected rate of return.

However, the complementary effect of public investment on private investment may be offset by the crowding-out effect. It is affirmed that public investment can crowd-out private investment in both physical and financial terms.

In physical terms if public investment produces marketable output that competes with private output, then private investment may be "physically" crowded - out (Khan \& Reinhart, 1990). In financial terms the are two ways in which crowding-out can take place. Firstly, the case where a higher real interest rate crowds-out a certain amount of private investment that would otherwise have taken place. If the higher real interest rate is a function of the level of 
public investment, then, a rise in public investment may cause private investment to decline. The real interest rate may be expected to rise because of the higher demand for credit by the public sector needed to finance additional public investment. The second way considers the case where the finance of public investment lowers the availability of financial resources to the private sector, thus hampering private investment. If public investment is financed, say, by diverting funds from commercial and development banks through reserve requirements increases, then credit to the private sector may be shrank.

Wai and Wong (1982) develop a recursive model to estimate net effect of public investment on private investment. Private investment $\left(\mathrm{IP}_{\mathrm{t}}\right)$ in specified in their model as a function of public investment $\left(\mathrm{IG}_{\mathrm{t}}\right)$, the change in the stock of credit given to the private sector (domestic and net foreign capital inflows) $\left(\mathrm{FP}_{\mathrm{t}}\right)$, and the lagged stock of capital of the private sector $\left(\mathrm{KP}_{(\mathrm{t}-1)}\right)$ :

$$
\mathrm{IP}_{\mathrm{t}}=\mathrm{c}_{0}+\mathrm{c}_{1} \mathrm{IG}_{\mathrm{t}}+\mathrm{c}_{2} \mathrm{FP}_{\mathrm{t}}+\mathrm{c}_{3} \mathrm{KP}_{(\mathrm{t}-1)}
$$

The complementary effect of public investment is measured by the public investment coefficient, $c_{1}$. To internalize the crowding-out effect, credit given to the private sector is then specified as a residual of total credit $\left(\mathrm{F}_{\mathrm{t}}\right)$ less credit given to the public sector $\left(\mathrm{FG}_{\mathrm{t}}\right)$ :

$$
\mathrm{FP}_{\mathrm{t}}=\mathrm{F}_{\mathrm{t}}-\mathrm{FG}_{\mathrm{t}}
$$

...while credit to the public sector is specified as a function of public investment $\mathrm{IG}_{\mathrm{t}}$ :

$$
\mathrm{FG}_{\mathrm{t}}=\mathrm{g}_{0}+\mathrm{g}_{1} \mathrm{IG}_{\mathrm{t}}
$$

Substituting equation (3) in equation (2), and in turn, substituting $\mathrm{FP}_{\mathrm{t}}$ in equation (1) leads to a reduced form equation which considers credit to the private sector as an endogenous variable in the model:

$$
\mathrm{IP}_{\mathrm{t}}=\mathrm{k}_{0}+\mathrm{k}_{1} \mathrm{IG}_{\mathrm{t}}+\mathrm{k}_{2} \mathrm{~F}_{\mathrm{t}}+\mathrm{k}_{3} \mathrm{KP}_{(\mathrm{t}-1)}
$$

The resulting coefficient of public investment, $\mathrm{k}_{1}=\mathrm{c}_{1}-\mathrm{c}_{2} \mathrm{~g}_{1}$, indicates the existence or otherwise of a crowding-out effect. The estimation obtained by $U$ tun Wai and Wong suggest, in the case of Mexico, the existence of crowding-out that completely offsets the contributory effect of investment for the sample period 1965-1975, since the estimated coefficient of public investment in the reduced equations is negative, $\mathrm{k}_{1}<0$, i.e., $\mathrm{c}_{2} \mathrm{~g}_{1}>\mathrm{c}_{1}$.

Galbis (1978) tests the relationship between public and private investment for a sample of 16 Latin-American countries from 1961 to 1973 . The ratio of private investment to income is specified as a function of the deposit of interest rate, inflation, the rate of return on capital and the ratio of public investment to income. Although the deposit interest rate and the rate of return on capital are omitted in the estimation because the unavailability of data at that time, the results of the time series regressions indicate both a complementary (crowding-in) and a substitution (crowding-out) relation between public and private investment in Latin-American economies. For the specific case of Mexico, he finds a complementary relation. Galbis concludes that the lack of a general pattern of behaviour suggest that "the institutional arrangements specific to each country are more important than general principles" (p.430).

Greene and Villanueva (1991) analyse a private investment function for a sample of 23 LDCs (including Mexico) from 1975 until 1987. To test the relation between public and private investment they divide the set of countries into two groups according to their private investment ratio: the first one includes $12 \%$. By analysing the public and private ratio is higher in the first one includes the countries where the private investment ratio to GDP is over $12 \%$, while the second group includes the countries where the ratio is below $12 \%$. By analysing the public and private ratio to GDP in both sets of countries, they find that a complementary relation seems to exist between public and private investment, since, on average, the public investment ratio is higher in the first group of countries, than in the second set of countries, which have a lower private investment to GDP ratio.

Afterwards, these authors specify a private investment function to test econometrically the determinants of private investment and the effect that public investment has on it. The ratio of private investment to GDP is specified as a function of the following variables: the real deposit interest rate, the lagged percentage change in real GDP per capita, the ratio of public investment to GDP, inflation, the lagged level of per capita GDP, inflation, the lagged level of per capita GDP, the lagged ratio of debt service payments to exports and the lagged ratio of the country's stock of external debt to its nominal GDP. Estimating the equation for the 23 countries in the sample, such authors find that the estimated coefficient of the public investment ratio is positive and significant in explaining private investment, suggesting complementarity between public and private investment. So, according to Greene and Villanueva's results, private investment is determined positively by the lagged rate of growth real per capita GDP and public investment, while the real interest rate, inflation, the lagged ratio of debt service payments to export and the lagged ratio of the stock of debt to GDP have a negative effect on private investment. 


\section{Methodology and Estimation Results}

Following Warman and Thirlwall (1994) two models to taste the net effect of public investment on private investment are then developed for the case of Mexico during the period 1970-2019 and for each of the two subperiods distinguished within it: 1970-1990 and 1991-2019 which will allow us to discern and compare such interaction under financial repression (Note 2) and the current one where a liberalised financial system prevails.

The main purpose of the econometric analysis is to evaluate the effect of a change in public investment on private one pondering the indirect effects that the former has on the latter through the real interest rate and through the availability of credit to the private sector investment the availability of credit to the private sector in the financial market. Therefore, the real rate of interest and the real stock of credit given to the private sector are included as explanatory variables. In consistency with the total investment function, and to test the sensitivity of private investment to changes in aggregate demand, the lagged change in the real level of GDP is also included as an explanatory variable. Before undertaking the major analysis, the estimates of a sort of baseline line model must be laid down to use them as parameters of reference. (Mukherjee et al., 1998)

\subsection{The Baseline Model}

The underlying hypothesis of the baseline model is that private investment is crowded-out through an increase in the real interest rate derived from the increased demand for credit by the public sector. So, pivoting on the total investment to explain private investment, and adding public investment as an explanatory variable gives the equation:

$$
\mathrm{I}_{\text {prv }}=\mathrm{a}_{0}+\mathrm{a}_{1} \mathrm{I}_{\mathrm{pbl}}+\mathrm{a}_{2} \mathrm{r}+\mathrm{a}_{3} \mathrm{CP}_{\mathrm{r}} \mathrm{S}+\mathrm{a}_{4} \Delta \mathrm{PIB}_{\mathrm{t}-1}
$$

...where: $\mathrm{I}_{\mathrm{prv}}$ is the level of real private investment, $\mathrm{I}_{\mathrm{pbl}}$ is the level of real public investment, $\mathrm{r}$ is the real interest rate, $\mathrm{CP}_{\mathrm{r}} \mathrm{S}$ is the stock of real credit given by the banking sector (commercial and development banks alike), to the private sector and $\Delta \mathrm{PIB}_{\mathrm{t}-1}$ is the lagged change in real GDP. The coefficient of public investment $\mathrm{a}_{1}$ measures the contributory effect of a rise in the public investment on private investment.

Equation (5) is estimated in natural logarithms (Note 3) and is regressed by Ordinary Least Squares (OLS) in each of subperiods proposed. Two dummy variables are included in the regression of the first subperiod: $1970-1990$ because private investment was significantly affected by the austerity measures imposed by the government after the abrupt oil-prices fall in 1986, and in 1988 when private investment was affected by the pact subscribed between public and the private sector which fix some key relative-macroeconomic prices of the Mexican economy in December 1987.

Accordingly, for the regression of the second subperiod: 1990-2019, two dummy variables are also incorporated. On one hand for 1996 as private investment was hardly hit by the tequila financial crisis nationally originated and other for 2009 as private investment is visibly lowered by the governmental austerity programmes set up worldwide by the financial and economic crises.

3.1.1 The result of estimating equation (5) is as follows

Baseline Model: MCO, sub-period:1970-1990, T = 30. Dependent Variable: Ln I $\mathrm{prv}_{\text {. }}$.

$$
\begin{array}{llll}
\mathrm{Ln} \mathrm{I}_{\mathrm{prv}}= & 0.17+0.001 \mathrm{r}+0.23 \ln \mathrm{I}_{\mathrm{pbl}}-0.0002 \Delta \mathrm{PIB}_{\mathrm{t}-1}+0.71 \ln \mathrm{CBS}_{\mathrm{prv}} \\
(3.9) & (0.54) & (3.21) & (-0.34)
\end{array}
$$

According to the estimated coefficients, $\mathrm{I}_{\text {priv }}$ is positively affected by a change in $\mathrm{I}_{\mathrm{pbl}}$. The estimated impact coefficient of a change in $\mathrm{I}_{\mathrm{pbl}}$ investment is $\alpha_{1}=0.39$, whereas the estimated elasticity of $\mathrm{I}_{\mathrm{priv}}$ with respect to $\mathrm{I}_{\mathrm{pbl}}$ is ế $\alpha_{1}$ $=0.23$. A $10 \%$ in $\mathrm{I}_{\mathrm{pbl}}$ is associated with a rise in $\mathrm{I}_{\text {priv }}$ of $2.3 \%$ on average. The credit given to the private sector does seem to have a considerable positive effect on $\mathrm{I}_{\text {priv }}$, while the estimated coefficient of the $\mathrm{r}$ and of the lagged change in GDP are not statistically significant. Probably, the demand side effect is being captured by public investment, reducing the statistical significance of the lagged accelerator.

3.1.2 The result of estimating equation (5) is as follows

Baseline Model: MCO, Sub-period:1990-2019, T = 30. Dependent Variable: Ln I $\mathrm{p}_{\mathrm{rrv}}$.

$$
\begin{aligned}
& \text { Ln } \mathrm{I}_{\mathrm{prv}}=5.06+0.22 \ln \mathrm{I}_{\mathrm{pbl}}-0.02 \mathrm{r}+0.45 \ln \mathrm{CBS}_{\mathrm{prv}}-2.07 \ln \mathrm{PIB} \\
& \begin{array}{lllll}
(3.4) \quad(2.1) \quad(-1.1) & (4.6) & (-0.27) & \mathrm{R}^{2}=0.75
\end{array}
\end{aligned}
$$

According to the estimated coefficients, $\mathrm{I}_{\text {priv }}$ is positively affected by a change in $\mathrm{I}_{\mathrm{pbl}}$ too. The estimated impact coefficient of a change in $\mathrm{I}_{\mathrm{pbl}}$ is $\alpha_{1}=0.32$ while the estimated elasticity of $\mathrm{I}_{\text {priv }}$ with respect to $\mathrm{I}_{\mathrm{pbl}}$ is ế $\alpha_{1}=0.22$. A $10 \%$ in $\mathrm{I}_{\mathrm{pbl}}$ is associated with a rise in $\mathrm{I}_{\text {priv }}$ of $2.2 \%$ on average. As before, the credit given to the private sector does seem 
to have a considerable positive effect on $\mathrm{I}_{\mathrm{prv}}$ while the estimated coefficient of the real interest rate and of the lagged change in GDP are not statistically significant.

\subsection{Model 1}

Owing to coefficient $\mathrm{a}_{1}$ in equation (5) can overestimate the total effect since the financial crowding-out effect is not explicitly considered, it is necessary to measure the crowding-out effect so to be able to estimate the net effect of public investment on private investment. To do this a recursive model is proposed.

Stating real interest rate as a positive function of public investment:

$$
\mathrm{r}=\mathrm{b}_{\mathrm{o}}+\mathrm{b}_{1} \mathrm{I}_{\mathrm{pbl}}
$$

Substituting (10) into (9) gives:

$$
\begin{aligned}
& \mathrm{I}_{\mathrm{prv}}=\alpha_{0}+\alpha_{1} \mathrm{I}_{\mathrm{pbl}}+\alpha_{2}\left(\mathrm{~b}_{\mathrm{o}}+\mathrm{b}_{1} \mathrm{I}_{\mathrm{pbl}}\right)+\alpha_{3} \mathrm{CP}_{\mathrm{r}} \mathrm{S}+\alpha_{4} \Delta \mathrm{PIB}_{\mathrm{t}-1} \\
& \rightarrow \mathrm{I}_{\mathrm{prv}}=\left(\alpha_{0}+\alpha_{2} \mathrm{~b}_{\mathrm{o}}\right)+\left(\alpha_{1}+\alpha_{2} \mathrm{~b}_{1}\right) \mathrm{I}_{\mathrm{pbl}}+\alpha_{3} \mathrm{CP}_{\mathrm{r}} \mathrm{S}+\alpha_{4} \Delta \mathrm{PIB}_{\mathrm{t}-1}
\end{aligned}
$$

Obtaining the reduced form equation:

$$
\mathrm{I}_{\mathrm{prv}}=\mathrm{c}_{0}+\mathrm{c}_{1} \mathrm{I}_{\mathrm{pbl}}+\mathrm{c}_{2} \mathrm{CP}_{\mathrm{r}} \mathrm{S}+\mathrm{c}_{3} \Delta \mathrm{PIB}_{\mathrm{t}-1}
$$

where: $c_{0}=\alpha_{0}+\alpha_{2} b_{0}, c_{1}=\alpha_{1}+\alpha_{2} b_{1}, c 2=\alpha_{3}$ and $c_{3}=\alpha_{4}$

As a result, the coefficient $c_{1}$ measures the net effect of public investment on private investment. If $c_{1}<\alpha_{1}$, then there is crowding out working through the real interest rate. However, if $c_{1}>0$ the net effect is positive. If $c_{1}<0$, crowding out offsets the contributory effects and the net effect of public investment on private investment is negative.

The first model considers the equation (9) as the private investment function, considering that $\mathrm{I}_{\text {prv }}$ investment may be crowded-out by $\mathrm{I}_{\mathrm{pbl}}$. If the public sector increases its demand for credit and reduce the availability of credit to the private sector. If credit to the public sector $\left(\mathrm{CP}_{\mathrm{u}} \mathrm{S}\right)$ is stated as a positive function of $\mathrm{I}_{\mathrm{pbl}}$ :

$$
\mathrm{CP}_{\mathrm{u}} \mathrm{S}=\beta_{0}+\beta_{1} \mathrm{I}_{\mathrm{pbl}}
$$

.... and credit to the private sector is determined as the residual of total credit given by the banking sector (TC) (Note 4) less credit given to the public sector:

$$
\mathrm{CP}_{\mathrm{r}} \mathrm{S}=\mathrm{TC}-\beta_{1} \mathrm{I}_{\mathrm{pbl}}
$$

Substituting (14) and (15) into (9) gives:

$$
\begin{aligned}
\quad I_{p r v}=a_{0}+a_{1} I_{p b l}+a_{2} r+a_{3}\left(T C-\beta_{0}-\beta_{1} I_{p b l}\right)+a_{4} \Delta \text { PIB }_{t-1} \\
\rightarrow I_{p r v}=\left(a_{0}-a_{3} \beta_{0}\right)+\left(a_{1}-a_{3}\right) I_{p b l}+a_{2} r+a_{3} T C+a_{4} \Delta \text { PIB }_{t-1}
\end{aligned}
$$

Leading to the reduced form equation:

$$
\mathrm{I}_{\mathrm{prv}}=\delta_{0}+\delta_{1} \mathrm{I}_{\mathrm{pub}}+\mathrm{a}_{2} \mathrm{r}+\mathrm{a}_{3} \mathrm{TC}+\mathrm{a}_{4} \Delta \mathrm{PIB}_{\mathrm{t}-1}
$$

...where: $\delta_{0}=\alpha_{0}-\alpha_{3} \beta_{0}, \delta_{1}=\alpha_{1}-\alpha_{3} \beta_{1}, \delta_{1}=\alpha_{2}, \delta_{3}=\alpha_{3}$ and $\delta_{3}=\alpha_{4}$

If $\delta_{1}<\alpha_{1}$, there is financial crowding out working through the reduction in the availability of credit to the private sector. If $\delta_{1}<0$, the crowding-out effect offsets the contributory effect.

\subsection{Estimation Results}

3.3.1 The result of estimating equation (11) is as follows

Model 1: MCO, 1970-1990, (T=30). Dependent variable: $\operatorname{Ln}_{\text {priv }}$

$$
\begin{aligned}
& \text { Ln } \mathrm{I}_{\text {priv }}=0.07+0.21 \ln \mathrm{I}_{\mathrm{pbl}}+0.74 \ln \mathrm{CBS}_{\mathrm{prv}}-0.0003 \mathrm{PIB}_{\mathrm{t}-1} \\
& \text { (0.19) (3.52) (8.50) (-0.84) } \quad \overline{\mathrm{R}}^{2}=0.75 \quad \mathrm{~N}=29
\end{aligned}
$$

The equation is well determined and shows the expected signs. The impact coefficient of a change in $\mathrm{I}_{\mathrm{pbl}}$ on $\mathrm{I}_{\mathrm{prv}}$ derived from equation (17) is $\mathrm{c}_{1}=0.21\left(\overline{\mathrm{I}}_{\mathrm{prr}} / \overline{\mathrm{I}}_{\mathrm{pbl}}\right)=0.36$, where $\overline{\mathrm{I}}_{\mathrm{prv}}$ and $\overline{\mathrm{I}}_{\mathrm{pbl}}$ are the average values of private and public investment, respectively. Comparing the coefficient $\mathrm{c}_{1}$ derived from the reduced form equation, with the coefficient of public investment in equation (5), it is found that $c_{1}$ is positive and lower than $\alpha_{1}$; i.e. $0<c_{1}=0.36<\alpha_{1}=0.39$. However, considering the estimated elasticities of private investment with respect to public investment, $\hat{\varepsilon} \alpha_{1}=0.23$ in equation (5) and $\hat{\varepsilon} c_{1}=0.21$ in equation 17 , a test was undertaken to see if $\hat{\varepsilon} \alpha_{1}$ and $\hat{\varepsilon} c_{1}$ are statistically different. Knowing beforehand that the standard error of $\hat{\varepsilon} c_{1}$ is $\hat{S} \hat{\varepsilon} c_{1}=0.58$, and the critical t-value at a 5 percent significance level is 1.746 , a statistic $Z=\hat{\varepsilon} \mathrm{c} 1-\hat{\varepsilon} \alpha_{1} / \hat{S} \hat{\varepsilon} \mathrm{c}_{1}=0.33$ is found and that it lies in the range where the hypothesis $\hat{\varepsilon} \mathrm{c}_{1} \neq$ $\hat{\varepsilon} \alpha_{1}$ is rejected. According to these results, $c_{1}$ and $\alpha_{1}$ are not statistically different which does not support the 
hypothesis that there is crowding-out of the $\mathrm{I}_{\mathrm{prv}}$ working through a rise in the real interest rate, caused, in turn, by the public investment.

3.3.2 The result of estimating equation (11) is as follows

Model 1: MCO, 1990-2019 ( $\mathrm{T}=30)$. Dependent variable: $\mathrm{Ln} \mathrm{I}_{\text {priv }}$

$$
\begin{aligned}
& \mathrm{L}_{\mathrm{n}} \mathrm{I}_{\text {priv }}=6.45+0.18 \mathrm{Ln} \mathrm{I}_{\mathrm{pbl}}+0.40 \mathrm{LnCBS}_{\mathrm{prv}}-0.78 \mathrm{Ln} \mathrm{PIB}_{\mathrm{t}-1}
\end{aligned}
$$

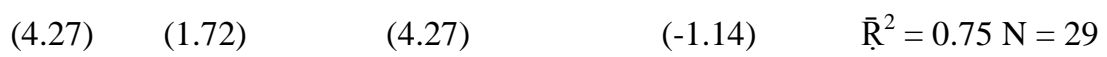

If $c_{1}<\alpha_{1},(0.18<0.22)$ an effect crowding-out effect of the $\mathrm{I}_{\text {prv }}$ working through a rise in the real interest rate, caused, in turn, by the $\mathrm{I}_{\mathrm{pbl}}$. Notwithstanding this inference needs to be qualified as the $\mathrm{I}_{\mathrm{pbl}}$ has registered a long wanning descent since the financial system went liberalised in 1989.

\subsection{Model 2}

The second model also considers equation (5) as the private investment function, considering that private investment may be crowded-out by public sector investment increases its demand for credit and reduced the availability of credit to the public sector.

Recurring to the functional form of a recursive model, credit is assumed to be a positive function of public as investment:

$$
\mathrm{CP}_{\mathrm{u}} \mathrm{S}=\beta_{0}+\beta_{1} \mathrm{I}_{\mathrm{pbl}}
$$

... and that credit to the private sector is determined as the residual of total credit given by the banking sector $\left(\mathrm{C}_{\text {Tot }}\right)$ (Note 5) less credit given to the public sector:

$$
\mathrm{CP}_{\mathrm{r}} \mathrm{S}=\mathrm{C}_{\mathrm{Tot}}-\mathrm{Cp}_{\mathrm{u}} \mathrm{S}
$$

Substituting (19) and (20) into (5) gives:

$$
\begin{gathered}
I_{p r v}=a_{0}+a_{1} I_{p b l}+a_{2} r+a_{3}\left(C_{T o t}-\beta_{0}-\beta_{1}\right)+a_{4} \Delta G P_{t-1} \\
I_{p r v}=\left(a_{0}+a_{1} \beta_{0}\right)+\left(a_{1}-a_{3} \beta_{1}+I_{p b l}+a_{2} r+a_{3} C_{T o t}+a_{4} \Delta G D P_{t-1}\right.
\end{gathered}
$$

Leading to the reduced form equation:

$$
\mathrm{I}_{\mathrm{prv}}=\delta \mathrm{a}_{0}+\delta_{1} \beta_{1}+\delta_{2} \mathrm{r}+\delta_{3} \mathrm{C}_{\mathrm{Tot}}+\delta_{4} \Delta \mathrm{GDP}_{\mathrm{t}-1}
$$

...where; $\delta 0=\mathrm{a} 0-\mathrm{a} 3 \mathrm{~b} 0 ; \delta 1=\mathrm{a} 1-\mathrm{a} 3 \mathrm{~b} 1 ; \delta 2=\mathrm{a} 2 ; \delta 3=\mathrm{a} 3 ; \delta 4=\mathrm{a} 4$. If $\delta 1<\alpha 1$ there is financial crowding out working through a reduction in the availability of credit to the private sector. If $\delta 1<0$ the crowding out effect offsets the contributory effect.

3.4.1 The result of estimating equation (23) is as follows

Model 2: MCO, 1970-1990, (T = 30). Dependent Variable: $\operatorname{Ln}_{\text {priv }}$

$$
\begin{array}{r}
\log \mathrm{I}_{\mathrm{prv}}=1.37+0.006 \mathrm{r}+0.18 \log \mathrm{I}_{\mathrm{pbl}}+0.002 \Delta \mathrm{PIB}_{\mathrm{t}-1}+0.43 \log \mathrm{TC}-0.27 \mathrm{DU}_{86}+0.01 \mathrm{DU}_{88} \\
\begin{array}{rrrrr}
(4.57) & (3.31) \quad(2.28) & (2.78) & (5.76) & (-2.84) \\
\mathrm{R}^{2}=0.89 & \mathrm{DW}=1.49 & \mathrm{~F}(6,14)=20.9 & \mathrm{~N}=21
\end{array}
\end{array}
$$

The comparison of the coefficient of public investment $\delta 1=0.18\left(\overline{\mathrm{I}}_{\mathrm{prv}} / \overline{\mathrm{I}}_{\mathrm{pbl}}\right)=0.31$ with $\alpha_{1}=0.39$ would seem to indicate that there is crowding out of private investment working through the availability of credit to the private sector. Nevertheless, testing the hypothesis of the estimated elasticity of private investment with respect to public investment in equation (5) being statistically different from that in equation (16), we find that the statistic $Z=\hat{e} \delta_{1}$ - ế $\alpha_{1} /$ Sế $\delta_{1}=0.62$, where the standard error of ế $\delta_{1}$ is $S$ ế $\delta_{1}=0.0805$, remains within the range where the null hypothesis ế $\delta_{1} \neq$ ế $\alpha_{1}$ is accepted since $\mathrm{Z}<\mathrm{t}_{(14) ; 0.95}=1.761$. Hence, according to the empirical results obtained, it cannot be concluded that a rise in public investment crowds-out private investment by reducing the availability of credit to the private sector.

3.4.2 The result of estimating equation (23) is as follows

Model 2: MCO, 1990-2019, (T = 30), Dependent Variable: $\operatorname{Ln}_{\mathrm{prv}}$

$$
\begin{aligned}
& \text { Ln } \mathrm{I}_{\mathrm{prv}}=7.9-0.14 \ln \mathrm{I}_{\mathrm{pbl}}-0.02 \mathrm{r}+0.55 \ln \mathrm{CB}_{\mathrm{Tot}}-1.57 \mathrm{Ln} \mathrm{PIB}+\mu
\end{aligned}
$$

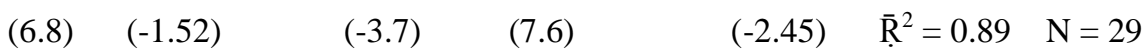

If $\delta 1<0$ the influence of the crowding-out effect of the $\mathrm{I}_{\text {prv }}$ offset the influence of the crowding-in effect due to an argued reduction of the credit available in the financial system. This is, there is not a clear influence of the public investment on the private investment as a result. 
In a nutshell, the empirical evidence obtained in this section of the analysis suggests that there is no financial crowding-out of private investment caused by a rise in public investment either working through a rise of interest rates or through the availability of credit to the private sector. In both cases, the net effect of a change in public investment in one of complementarity.

\section{Concluding Remarks and Discussion}

In Mexico, the theoretical role of the public sector in financial policy under a liberalised financial system has been limited to the surveillance of the money and capital markets. It can be argued that under a liberalised financial model, the development role of the Bank of Mexico is reduced, if not abandoned. Its main objective cease to be the allocation of credit to preferential sectors of the economy with the aim of promoting economic growth. Instead, financial policy is oriented towards the maintenance of prices and exchange stability, to the development of a money market and to the supervision of the financial system. Furthermore, having the government decreed the autonomy of the Bank of Mexico (1997), with de ensuing handover of the credit policy to the commercial banks, the public sector has brought one of its main instruments of political economy to a halt.

Financial liberalisation and market oriented economic policies imply a reduction in public expenditure. Such contraction has affected mainly public investment for the case of Mexico.

The results obtained as far as the net effect of public investment on private investment is concerned, suggests that the public investment is not at the expense of private investment: no evidence of financial crowding-out of private investment of public investment was found.

There is no reason to believe that a rise in public expenditure will crowd-out private investment. On the contrary, it seems that a rise in public investment can encourage private investment and rises the levels of productivity of investment.

Even though financial liberalisation could raise the level of total or private real savings, its effect on financial savings can only have a positive impact on private investment and growth if these are more productive than other forms of savings as idle resources might to find more profitable use via financial intermediaries if financial savings lead to productive investment and do not remain in the financial sector for speculation purposes. Notwithstanding, it cannot be assumed that financial savings find productive investment outlets automatically. This highlights the importance of a sound economic environment for private investment to take place. In the case of Mexico, besides the need for an expanding internal market and the expectations of high returns on investment, the trust of the private sector in the sector public's economic policies play a crucial role in the private sector's decisions for the demand industrial-agricultural projects. Hence, is beneficial for economic policy to restore and maintain the conficence on the private sector in the government.

\subsection{Discussion}

After three decades of putting into practice the financial reform, i.e., a liberalised financial system and an independent central bank, the macroeconomic performance of Mexico has been characterized by a chronic deficiency of effective demand as the economic model was mounted in a tripod of: undervalued labour, overvalued exchange rates with high interest rates, and a financially "sterilised" public-sector. This is rather disappointing particularly in terms of productivity-growth due to the Mexican economy has failed to produce high added-value goods and it has ended up being settlement of a large in-bond industry, exporting raw commodities, low-productivity, low-wage employment, remarkably asymmetric distributional outcomes, and one lucrative finance.

To delve into the attributable effects to the financial reform problems from other factors in the functioning of the Mexican economy and then to deliver some elements of a new strategy, this study has been worked a theoretical financial-liberalisation hypothesis out, which postulates that the increase of the public investment can financially crowd-out private investment. Thus, in departing from other research that used to work with the overall time series data, this work chooses a time large enough that its partitioning into pre-reform and post-reform stages that allows to empirically not only validate such hypothesis but also compare the results between sub-periods defined, let alone the use of better statistical data. Notwithstanding, a caveat should be put forward. The results must be cautiously taken due to the resources demanded directly for the public sector from commercial banks by economic policy and those channelised through the development banks have been less robust in the period spanning from 1990 to 2020 than those assigned in the $1970-1990$ subperiod. So that, the test of the hypothesis of whether the crowding-in or the crowding-out effect of public investment on private investment prevails at the end of the day, it seems to be slightly weakened. Therefore, it should be taken with a pinch of salt too.

If industrialisation still stands as the best route to development in the agenda of Mexico, future research must tackle 
the challenges imposed by the rising of the intangible economy whose properties are fundamentally different from those of tangibles as the later do not acquire any physical form whatsoever but it is disembodied in assets that create greater value for their owners but also appalling effects for LDCs which have seen foreign-direct investment inflows reduced and in doing so unemployment has arisen, inequality deepened and productivity slowed. Before this backdrop in which many of the old rules do badly not only governments must have to redesign industrial policy carefully but also studious and practitioners of economics, as a discipline, has the imperative for the refinement of key concepts like productivity itself. Future research must improve the measurement of productivity as that provided by the ICOR which does not ponder the impact of other financing sources of investment so over-estimating the role of loanable funds pouring from the system bank onto the economic activity. And, more importantly, such index says almost nothing about the spill-overs in a competitive modern economy which may exhibits some contradictory effects, i.e., on the one hand, share benefits to other firms or economies but, on the other hand, it might also to weaken the incentives to invest.

\section{Acknowledgements}

The research is financed by DGAPA-UNAM by means of the project IN311620.

\section{References}

Banco de Mexico. (2021). Informe anual y compilación de informes trimestrales. Banco de Mexico. Retrieved from https://www.banxico.org.mx/publicaciones-y-prensa/informes-anuales/informes-anuales-economia-ban.html

Cypher, J. M., \& Dietz, J. L. (1997). The Process of Economic Development. London: Routledge.

Galbis, V. (1978). Money, Investment and Growth in Latin America, 1961-1983. Economic Development and Cultural Change, 27(3). https://doi.org/10.1086/451108

Greene, J., \& Villanueva, D. (1991). Private investment in Developing Countries; an Empirical Analysis. International Monetary Fund Staff Papers, 38(1).

Haskel, J., \& Westlake, S. (2018). Capitalism without Capital: the rise of the intangible economy. New Jersey: Princeton University Press. https://doi.org/10.1515/9781400888320

Khan, M. S., \& Reinhart, C. M. (1990). Private Investment and Economic Growth in Developing Countries. World Development, 18(1). https://doi.org/10.1016/0305-750X(90)90100-C

Mukherjee, C., White, H., \& Wuyts, M. (1998). Econometrics and Data Analysis for Developing Countries. London: Routledge.

Palma, J. G. (2010). Why has productivity growth stagnated in most Latin American countries since the neo-liberal reforms? Cambridge Working Papers in Economics (CWPE). https://doi.org/10.1093/oxfordhb/9780199571048.013.0023

Ros Bosch, J. (2013). Rethinking Economic Development, Growth, and Institutions. Oxford: Oxford University Press.

Wai, U. T., \& Wong, Ch. (1982). Determinants of Private Investment in Developing Countries. The Journal of Development Studies, 19(1). https://doi.org/10.1080/00220388208421848

Warman, F., \& Thirlwall, A. P. (1994). Interest rates, saving, investment and growth in Mexico 1960-90: Tests of the financial liberalisation hypothesis. Journal of Development Studies, 30(3). https://doi.org/10.1080/00220389408422330

\section{Notes}

Note 1. As Palma (2010) points out, with the liberalisation of the financial sector LDCs like Mexico were able to obtain market discipline and more competition, but that left little investment incentives, i.e., less capabilities to make industrial policy.

Note 2. The policies and instruments, such as credit ceilings and reserve requirements judged to divert financial resources to the public sector conform what is understood as a financial repression.

Note 3. Furthermore, estimating this and the rest of specified models allow us to interpret the estimated coefficients as elasticities. 
Note 4. Including commercial and development banks.

Note 5. Commercial and development banks alike.

\section{Copyrights}

Copyright for this article is retained by the author(s), with first publication rights granted to the journal.

This is an open-access article distributed under the terms and conditions of the Creative Commons Attribution license (http://creativecommons.org/licenses/by/4.0/). 